\title{
QUALITATIVE STUDY: TEACHER-STUDENT INTERACTIONS IN A JUNIOR HIGH SCHOOL CLASSROOM IN BATAM CITY
}

\author{
Nurlaily $^{1}$, Sally ${ }^{2}$ \\ ${ }^{1}$ Universitas Internasional Batam \\ ${ }^{2}$ Universitas Internasional Batam \\ ${ }^{1}$ nurlaily@uib.ac.id, ${ }^{2}$ sallykho11th@gmail.com
}

\begin{abstract}
This study aims to elaborate on the classroom interactions between an English teacher and seventhgrade students SMP Theodore Batam in teaching-learning English. This study employed a descriptive qualitative study on teacher's instructions and teacher-student interactions. To analyze the data, some data collection steps were carried out. The researchers used observation, fieldnote and, interview to obtain the data. The results illustrated that the teacher actively involved the students to engage in the learning process. The classroom activities were conducted without any significant problems because the teacher implemented a teaching approach to make the material easier to be learned and the students were cooperative in joining the lesson. However, it was found that most of the interactions were set up by the teacher. It is important to find a suitable approach and teaching method, so the students will be able to show more confidence in initiating interaction. Furthermore, the teacher should set good time management in applying a specific teaching approach.
\end{abstract}

Keywords: Classroom Interaction, English Class, Teacher-Student Interaction

\section{INTRODUCTION}

The number of attentions related to classroom interactions involving teachers and students has been growing. Class interaction is considered as a way to see the objective assessment of teacher-student performance in the classroom and the analysis of teaching that has been done effectively (Tsui, 2008). This process is influenced by the physical environment, socioeconomic and cultural backgrounds of students, and their psychological dimensions. This shows that all activities in the teaching-learning process will show various results of communication between teachers and students.

Many types of research have supported the idea that teachers have significant tasks in implementing teaching strategies in the classroom. Teaching and learning process shall be applied using several methods of teaching and learning. The stages imply the steps of forming teaching-learning. The procedure is called as an approach (Arora, 2017). Some examples of approaches used in classroom context are Evaluation Approach, Management Approach, Genre-based Approach, Multimedia approach. It is necessary for the teachers to have specific roles to assist the students class' activities. The importance of a teacher's role in the teachinglearning process is also found by (Astuti, 2016). The study reported that the students agreed to name their teacher as the main reason why the classroom learning process becomes interesting. It was later explained that some other factors that influenced students' learning motivation are teacher's attitude, a supportive classroom atmosphere, understanding the importance of English, various learning resources and activities, and encouraging feedback from the teacher. 
In Indonesia, English has taught formally since the first year of junior high schools through the university level, even though many schools have taught it in elementary school. Most English teachers in Indonesia often decide to use the existing teaching materials for their students which include textbooks, CDs, and videos available in the bookstores and on the internet. There are not many teachers who prepare their teaching materials based on their instructional objectives (Harsono, 2017). This situation shows that it is not easy for English teachers to prepare learning materials for their students including designing and developing suitable EFL learning materials reflecting new contexts and goals. The quality and availability of instructional materials are important for English learners to be successful in classrooms as well as for teachers to engage the learners and improve their learning (Barone $\& \mathrm{Xu}, 2008$ ). How to select teaching materials for instruction and English learners to practice their language and literacy is as crucial as the instructional strategies that teachers apply during teaching.

The research on the classroom has been done by many researchers to evaluate how teachers conduct the teaching and learning process. One of the tools that widely used is Flanders' Interaction Analysis Categories (FIAC). It categorizes classroom talk into teacher talk and students talk (Tsui, 2011). Teacher talk is classified into two categories, which are indirect influence and direct influence. Meanwhile, student talk includes response and initiation (Richards, 2003; Tsui, 2011). Indirect influence consists of accepting feelings, praises or encouraging, accepting ideas of students, and asking questions. On the other hand, direct influence involves lecturing, giving directions, and criticizing or justifying authority. There is also silence or confusion which is also added as a part of a teacher and students' interaction in the classroom (Richards, 2003).

Many studies have analyzed student-teacher engagement during the English learning process. Sundari et al. (2017) concluded that when interacting and communicating with the students in the classroom, teachers do not strictly follow the IRF structure. Regarding the interaction patterns in language classrooms, it was found that at least three modified IRF structures. Firstly, the teacher talking to the whole class is the most common pattern in the class, then students responded to the talk. The second pattern is teacher to the student individually by suggesting specific students. The student's response were expected and targeted response, confusion, or giving a non-verbal response. The last, teachers also set the class to work in pairs or in work to enable them to communicate and interact.

Besides, Huriyah \& Agustiani (2018) examined the class interactions that occur between teachers and students. Based on the results of the study, it can be concluded that the teacher dominated the class. The teacher was actively talking while the students were less active during teaching-learning activities. Student talk time was mostly used to respond to teacher questions and lectures. Teachers used more direct influence on their students rather than indirect influence. Moreover, the use of language was unbalanced in the classroom used by teachers and students. It was shown that the teacher used more Indonesian rather than English when explaining the material. Referring to the findings, it is suggested that teachers should optimize interactions to create a more dynamic and not monotonous classroom. The teacher should develop and improve basic skills in managing talk and techniques in giving appropriate questions and good feedback for students in the English class context.

Sagita (2018) also analyze English teacher and three learners interactions at SMPN 2 Sindang. The research used an interview and FIAC (Flanders Interaction Analysis Category). The results indicated that the teacher was more active than the learners. The total of teacher talk was $56.4 \%$. It was described that the teacher did not give a chance to the students to actively participate in 
classroom interaction. It was suggested that the teacher understands her role as a facilitator by giving opportunities for the students to initiate the interactions.

An interesting teaching material, suitable teaching strategies, and a good student-teacher interaction will increase the learning comfort and improve student achievement over time. Suryati (2015) has found that teachers still dominated the classroom interaction. The result of classroom observation showed interaction strategies, like teachers' extended turn, asking questions, and showing students' answers, were rarely illustrated. It led to a lack of student's participation in engaging classroom activities. Therefore, it is necessary to emphasize important aspects of the inside and outside classroom activities.

It is undeniable that schools in Batam City are demanded to maximize students' English skills as its location is near to other ASEAN countries, Singapore and Malaysia. The schools are expected to enhance students' English competencies by providing interactive and supportive learning activities. The teachers need not only implementing teaching strategies but also providing suitable learning resources. This study was conducted to describe the classroom interaction between the teacher and seventh-grade students. The interactions between an English teacher and the students were analyzed through observation. Interviewed was also conducted to complete the data from the observation. The results of this study are expected to provide information about a teacher and students that later encourage improvement in English classroom management.

\section{METHOD}

\section{Research Design}

The research design employed in this study is descriptive qualitative as it aims to get a clear description of the interaction between an English teacher and students in the classroom. Researchers in the qualitative study shall keep recording and taking notes of the activities to collect the data (Ary, Jacobs, Sorensen, \& Razavieh, 2010). They also should keep the obtained data well organized. The information covers the subject or samples of people observed, the selection process, contextual descriptions, methods of data collection, and other descriptive. Since the data needed in this study is a process that explains human behavior in its natural setting, the researchers decided to conduct a qualitative approach to this study.

\section{Research Participants}

The subject of this study was the seventh-grade students at SMP Theodore in the academic year of 2019/2020. The setting was in the English class taught by a male English teacher in the odd semester. The data of the study were collected in the form of observation field notes and interviews. The classroom interactions were observed to know how the teacher and the students (as the participants) interacted in English. The field note was also used to add information in the descriptive report. In addition, an interview done after the observation was to know the teacher's and student's understanding, belief, opinion, and experience about English learning in which its realization is seen in the class observation.

\section{Data Collection Technique}

The data collection activities were carried out through several steps. First, the researchers completed some administrative procedures, including permission to collect data at the school. As soon as the permission was obtained, the researchers met the English teacher to explain the purpose of this study as well as to ask permission for the observation process. The data in this 


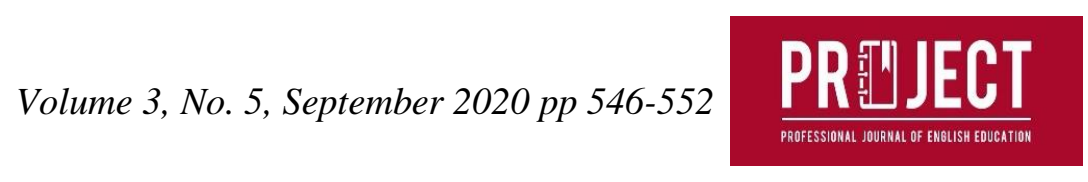

study were in the form of words gathered from the fieldnotes, and were mainly taken from observation results. The data to be analyzed in this study were the data of the teacher-student interaction in the classroom.

\section{Data Analysis Techniques}

After obtaining data from the research instruments used in this study, the researchers directly analyzed them. The data were described qualitatively in order to the results. The researchers draw summary by comparing data from the observation, field notes, and interview. It was to verify the answers of research problems. Hence, the researchers are able to get conclusions about the interactions between the teacher and students Grade 7 at SMP Theodore, Batam.

\section{RESULTS AND DISCUSSION}

\section{Results}

\section{Classroom Activity}

The English teacher at SMP Theodore's applied a Genre-based method to teaching English in the classroom. The reason that the teacher chose a Genre-based Approach was to help students understand the teaching content was simpler and more successful. As mentioned by the teacher, he only employed three of four steps in a genre-based approach. Sometimes, the teacher only applied three steps, Building Knowledge of the Field (BKOF), Modeling of the Text (MOT), and one of these two; Joint Construction of the Text (JCOT) or Independent Construction of the Text (ICOT). The teacher claimed that it took more time to implement all the steps, yet sometimes the duration of the teaching was not enough to apply all the steps.

The teacher at SMP Theodore implemented a Genre-based approach in teaching English in the classroom. He used the two or three stages of a Genre-based Approach, namely Building Knowledge of the Field (BKOF), Modeling of the Text (MOT), Joint Construction of the Text (JCOT), and Independent Construction of the Text (ICOT). All stages were employed by the teacher in the classroom activity. However, the teacher did not apply all of them. The teacher sometimes only implemented three stages, Building Knowledge of the Field (BKOF), Modeling of the text (MOT), and Joint Construction of the Text (JCOT). The reason why the teacher used a Genre-based Approach was that it was easier and more effective to make students comprehend the teaching material.

The teacher also opened up the discussion by greeting the students. The teacher, then, would start the lesson with several activities. The teacher gave the questions from the previous meeting related to the topic, and also asked about the students' assignments. Those actions were carried out to gain the attention of the students, to attract them, and to appreciate the lesson from the start.

The teacher elaborated and discussed the learning objectives and explained the final exam that would be done by the students both at the beginning and the end of the class. It aimed to emphasize the importance of the topic and teaching material that was explained to the students. There were many activities in the classroom done by the teachers to engage the students. The activities in Building Knowledge of the Field (BKOF) stage were questions and answers session, a picture or text description, and explanation. In the Modeling of Text (MOT) stage, the teacher provided the models of text to students. Its purpose was to give an illustration to the students what the models of the text look like. After that, the teachers instructed the students to 
make a group in the Join Construction of Text (JCOT) stage. Finally, the teacher gave the task in Independent of the Text (ICOT) stage.

Even though the teacher implemented the Genre-based approach stages, it was not enough to help improve students' English skills. This, of course, was influenced by the implementation that was not maximized. From the interview, the teacher said it was due to the insufficient duration of learning for the implementation of all stages. He also added that he still wanted to implement the approach based on the material or learning topic by adjusting the duration of time.

In the MOT staged previously mentioned, the activity was done by the teacher providing a model of tenses. However, the teacher used his notebook as the handbooks to teach the students, and the students were told to take notes. This kind of activity caused the lack of students' interaction at the beginning of the lesson. Nevertheless, it was later shown that the students participated in answering and giving feedback to the teacher.

\section{Classroom Interactions}

The teacher gave opportunities to all students, so they participated and actively engaged in the lesson. The teacher generally asked questions to involve the students in the learning process. The teacher started the class by asking about their previous lesson and introducing the topic on that day. It was often found that he liked asking questions randomly to the students. The teacher said that it helped him to know whether the students understood the material or not, so he always needed students' answers or feedback after delivering the material. When he knew there was a student who did not understand yet, he would re-explain the material slowly. This kind of interaction kept the students engaged in the classroom activity.

In conducting a learning process, the teacher at SMP Theodore showed a positive performance. Firstly, the teacher accepted the students' answers, questions, or feedback. The students were able to convey their idea and responded to the teacher's talks. Even some students asked the teacher to repeat what he had explained previously. The teacher also illustrated praises and encouragement during the lesson. The teacher would say "Great!", "Excellent", "Good answer!", or "That's correct" whenever the students were able to answer or responded to the teacher's questions. The teacher always appreciated students' responses even though they could not answer correctly. To accept the ideas from the students, the teacher also would interpret and simplify what the students said, so others could understand what the conclusion was.

During lecturing, the teacher dominantly explained about the material because he often initiated interactions. However, it was followed by students' replies, either comments or questions. The students still had chances to actively participate in the learning process since the teacher often gave chances for the students. The students well engaged in the learning process, and responded to the teacher's explanation. The teacher also instructed the students to do tasks or to discuss the material. It was clearly shown that they had fun learning with the teacher because the teacher made the atmosphere in the classroom more friendly as he loved telling funny stories. There was no negative behavior from the students as they always paid attention and showed good performance. As a result, the teacher never got angry or warned the students to keep silent.

\section{Discussion}

From the findings, it was found that classroom activity ran smoothly. The teacher implemented a Genre-based Approach as one of his ways to make the teaching material easily comprehended by the students. However, it still needs improvement in the implementation as the teacher said 
that he did not have enough time to employ the stages of the teaching approach completely. This finding illustrated that teaching material shall be delivered in good quality and complete form as it is the most significant aspect of English teaching (Barone \& Xu, 2008). The teacher has responsibilities to make sure the learning outcomes and learning objectives have been met after the teaching process is done.

From the observation results, it has also been found that there were interactions between the English teacher and students. The students have participated in the learning process where the teacher explains and asks questions, students are able to answer and respond to give their ideas. The teacher also receives positive student input where the teacher always encourages students to talk. The students dared to give an opinion because the teacher never criticizes any opinions and answers of students as long as they show good action.

Based on the teacher's talk, it was found that the teacher showed all of them except criticizing/justifying students' performance as the students indicated positive performance. Yet, it was seen that teacher was dominant in the interaction process. The teacher mainly explained the material and instructed the students about the task. Most of the interactions were initiated by the teacher since he often asked questions to the students. The students were able to give their feedback which was later followed by the teacher's compliments. This finding is similar to research conducted by (Sagita, 2018). The research found that the teacher talked dominantly which she calculated as $56.4 \%$ of the class time. However, the students gave a good contribution to establishing the classroom interaction the same as what was found in this study.

Different from findings of research done by Sundari et al. (2017) which emphasized patterns of teacher and student interactions, this study further described how teachers and students interacted in the classroom. Interestingly, the results of the research showed the similarity of the results in which there were interactions between the English teacher and the students, both in a whole class and individually. The relationship between the teacher and student individually can be seen from how the teacher gave praise and accept ideas from each student. All students also interacted when there were opportunities given by the teacher both during discussion and self-talk.

\section{CONCLUSION}

It can be concluded that the English teacher was able to make the students participate in the classroom interaction by asking questions and encouraging them to talk. The teacher also provided a positive environment because he made the students comfortable to learn English. There was an effort from the teacher to implement a Genre-based approach in the learning activities to match the topic of the lesson. However, it still needs improvement in various aspects, especially regarding time management. It is suggested that the teacher tries other teaching approaches, so he can make the learning process more successful. Furthermore, it is necessary to find a suitable method to make the students initiate classroom interactions since the teacher still has to open the conversation.

\section{ACKNOWLEDGMENTS}

This study received financial support from Universitas Internasional Batam. The researchers were also thankful to the Research Institution and Community Service at Universitas Internasional Batam that has conducted selection process for research funding from the university. 


\section{REFERENCES}

Arora, N. (2017). English Language Teaching Approaches and Methodologies. New Delhi: McGraw Hill Education.

Ary, D., Jacobs, L. C., Sorensen, C. K., \& Razavieh, A. (2010). Introduction to Research in Education (8th ed.) (8th ed.). Wadsworth: Cengage Learning.

Astuti, S. P. (2016). Exploring Motivational Strategies. TEFLIN Journal, 27(1), 1-22.

Barone, D. M., \& Xu, S. H. (2008). Literacy Instruction for English Language Learners Pre$K$-2. New York: Guilford Press.

Harsono, Y. M. (2017). Designing and Developing Appropriate EFL Learning Materials Reflecting New Contexts and Goals. Proceedings of the Fifth International Seminar on English Language and Teaching (ISELT-5), 350-354.

Huriyah, S., \& Agustiani, M. (2018). An Analysis of English Teacher and Learner Talk in the Classroom Interaction. Linguistic, English Education and Art (LEEA) Journal, 2(1), 6071. https://doi.org/10.31539/leea.v2i1.385

Richards, K. (2003). Qualitative Inquiry in TESOL. In Qualitative Inquiry in TESOL. https://doi.org/10.1057/9780230505056

Sagita, I. (2018). Teacher Talk and Learner Talk in The Classroom Interaction (An Interaction Analysis to an English Language Class at SMP N 2 Sindang). Wiralodra English Journal, 2(1), 98-106. https://doi.org/10.31943/wej.v2i1.27

Sundari, H., Rafli, Z., \& Ridwan, S. (2017). Interaction Patterns in English As Foreign Language Classroom At Lower Secondary Schools. English Review: Journal of English Education, 6(1), 99. https://doi.org/10.25134/erjee.v6i1.775

Suryati, N. (2015). Classroom Interaction Strategies Employed By English Teachers At Lower Secondary Schools. TEFLIN Journal - A Publication on the Teaching and Learning of English, 26(2), 247. https://doi.org/10.15639/teflinjournal.v26i2/247-264

Tsui, A. B. M. (2008). Classroom Discourse: Approaches and Perspectives. In N. . Cenoz, J., \& Homberger (Ed.), Encyclopedia of Language and Education. https://doi.org/10.1007/978-0-387-30424-3

Tsui, A. B. M. (2011). The Routledge Handbook of Applied Linguistics. In J. Simpson (Ed.), The Routledge Handbook of Applied Linguistics (Vol. 1, pp. 274-286). https://doi.org/10.1558/cj.v1i3.23-31 